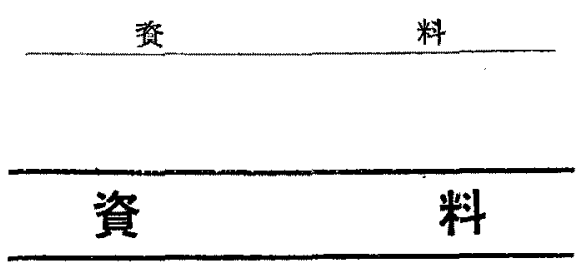

(昭和 25 年 6 月 24 日受理)

\title{
莏縮に關する最近の文献 (1)
}

果京工業大學 牧 島”邦 夫

\section{緒霉}

縮䄉に關するる理論を中心として最近（特に戰後）に 行われた種々の硅究を集錄した。戰前怯防縮に關する

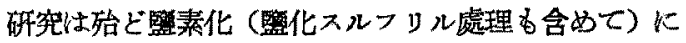
限られていだ。戰争中及び筞の後アメリカ，オースト ラッア，イギリス等に於て注目すべき種々の方法が登 見されて，この方面の研究㞹成り活況を是している。

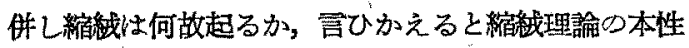
は未て゚一向に明汃されていない。相彎らず Speakman 一門の旅究陣及び Lipson, Freney 等法可成り 活弡な呼究を行つて居り，一方方、ストラッフの Stevenśon, $\Upsilon \times y \rightarrow \infty$ Harris, Am. CyanamidCo. 等る夫夕研究を淮めているようでするが，その理論生

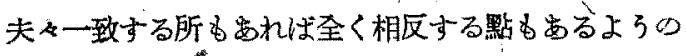
でる。

この種の研究は防縮處理に關連して，羊毛製品つ仕 上に於て極めて重要な題目でするにも拘らず，吾國で は殆ど手をつける人がない。最近防敘處理仕上等に關 する關心るむる程度高まつて来ているので，研究者の

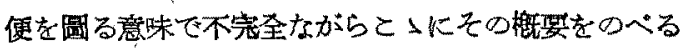
ととにした。

詳細なととに關しては文献が入手出來ないためにわ からないのてと〉では Chemical Abstract でわ加

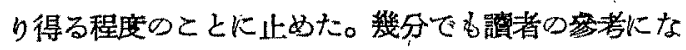
れば幸でする。

\section{1 羊毛の摩擦保數に關する研究}

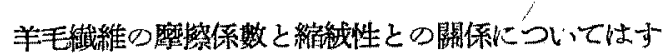

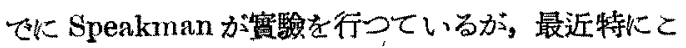
の種の研究が盛んでる，他の性質に比して比較的测
定しゃすいのもその原因の一つで苟ら5。

E. H. Mercer1) “'Stick-slip” Method なる方

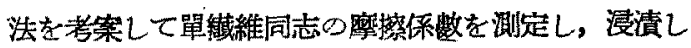
た液の $\mathrm{pH}$ Kよつて兩方向の杯檫俰數の差は異り，酸 性，テルカリ性でしの差が埼大し，又 $\mathrm{Ol}, \mathrm{Br}, \mathrm{SO}_{2} \mathrm{Cl}_{2}$ KOH 等て防縮處理を行万とこの差が低下するととか らとの值と縮絨性との聞の關連性を指摘した。

I. $\left.\mathrm{Bohn}^{2}\right)$ も上と同意見をもち，縮䋐速度は上の美 々り來る Differential frictional effect, これより 起る Fiber travelの速さの函数であるとと，これK

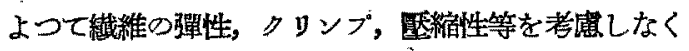
ても縮䄉現象の大部分を證明出來るととをのべた。

M. Lipson \& P. Howard 3 ) \& Horn \& Single fiber との摩擦係数を測定した。 $\mathrm{SO}_{2} \mathrm{Cl}_{2}$, alc. $\mathrm{KOH}$, aq. Br. aq. Cl. CCl Kとかした Cl, 等で紡縮處理を

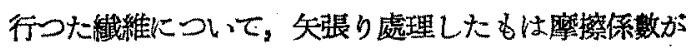
低下しているとと (alc. KOH は例外になつてい ととは注意すべきでするが觀測された。測定方沠に つ、ては尚，N. Gralén \& B. Oleffsson4) がその裝 置についてつへていい。そして第2報に於て，J. Lin-

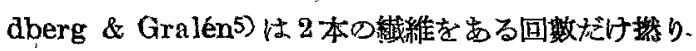
合わせててれを引離す祭炕荘する力を敗定し，てれよ り Static 及び Kinetic friction を求める方法を考。 案した。羊毛の場合，スケール方向に於ては frictional Coeft. と Normal Pressure の逆数との聞

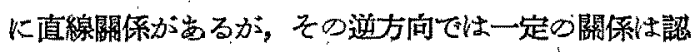
められず，スケールの形によつて樂る。又面白いとと には溫度が非常に大さな因子となり一般に温度が上る

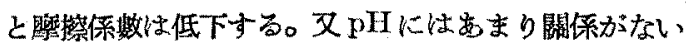
と言ふ。羊毛瀻維の表面を犯すような化學處理を行う と何れの方向の值る增加して居りその差は低下する。 
Melamine, Benzoquinone で處理したものは末處理

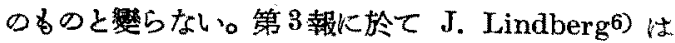
更にとの研究を續行し，羊毛繊維の表面は硬く滑かて， 化學又は機械的處理が行われるとスケールの存否には 關保なく，これが Rough となるか，皮質層(cortex)

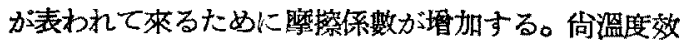
果法可逆的ですること登見した。第4報に於てJ. Lindberg \& N. Gralén 7)は各防縮處理の一つ-つ について測定を行つている。前と同樣にいゔれの場合 6摩擦係數は增大する。個々の場合についてその表面 構造の等化をのペている。Anion-active agent 中て 龧しく摩擦係數が低下するが，Cation-active 又梳 Nonionic detergents ではこの效果は見られないと い5，とれは注目すべき結果と思われる。との種の測 定については H. Buckle \& J. Pollitt,8) A. L. Smith \& M. Hurris9) 等の埌告もるが詳湅は不明 でる。尚可成り理諭的な研究を K.R. Makinson10) が行つている。

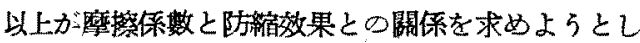
て行われた研究であるが，ま㙂納得の行く結果恃得ら れていない摩擦係數が堵加し，その方向性がなくな つてくれば何故縮性がなくなるか，この肝腎な點が わからない。文摩擦係數と繊維の膨潤性とは，その測 定方法と關連して密接な關係にあるように思われるが， ての點に關して餘り注意が拂われていないようにも思 われる。

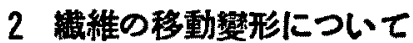

H. T. Rothwell11) は Milling 操作中比較的長 い瀻維は糸の中心部人，短い織維は糸の外側飞動く傾 向が岁るとと，又 C. S. Whewell， M. A. M. Eid， N. Kokmen \& M. C. Lui12) は50/50 の羊毛, カゼ イン繊維の交織織物は全毛織物よりもよく縮械するが, とれは羊毛織維の Travelling が容易になるために起 ること，又容易に戀形し得る瀻維を交ぜると Milling skrinkage が增大することを述へた。 A. J. P. Mar

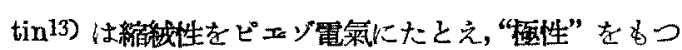
墭䧽(羊毛)の方向性に關して一風縤つた定性的理論を

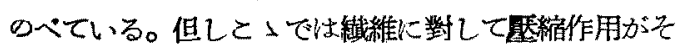
の原因となるととになり，かならずしも縮我操作迤 縮ばかりではないととに難點があるのではするまいか。

M. Harris ${ }^{14)}$ (瀻維の Curling が垂荘な因子 であるととを指摘している。何故かと言ふと，羊毛っ

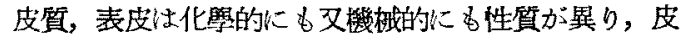
筫部估收縮する倾向をすつか，表皮部はこれをもたな い，この雨者の差があるためにとれによつて繊維に Curling が起り，これが綃䄾の原因となり得るといら のである

以上の諸說は縮諓現象を直接解明しようとしたもの であつて昔から大勢の研究者心よつて試みられている が今日未施完成に到らないるのである。縮䄉理論煌 粑をるつ者にとつては大きな關心事で岁るが，これに 關しては大しな發展は諮められない。向一般論として はP. Alexander ${ }^{15)}$ M. R. Frency16) 等の概說が女る。 前者纴 Milling はその夜の酸, アルカッ度によつて

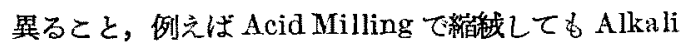
Milling では維絊しないるの，又との逆の作用をもつ ものがあることを指摘している。これは注目すべさ とで万ら。

\section{Speakman の研究}

羊毛の研究にたづさわるすのにとつて Speakman の名前は忘れるととの出來ないものである。戰前戰後 を通じて彼は矢張り活潑な矿究を續けている。こ〉に 一まとめにして彼の縮武作關する研究心概要をのぺて 怙とう。

T. Barr \& J. B. Speakman17) it Ethylene Sulfide を繊維中で重合させることによつて防縮效果が あらわれるとと, 及 Mercuric acetate, Benzoquinone も同樣な效果があるとと報告している。及 Menkart \& J. B. Speakman'8) ${ }^{1}$ Mercuric acetate

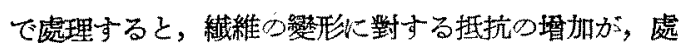

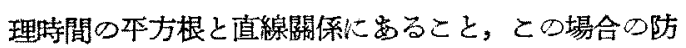

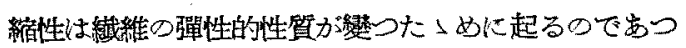
て，その彈性的性質の等化怢 Cross-linkage が增加 した〉めに生じたるのでるるとを結論した。との際 スケールは損賃されない19)。J. Menkart \& J. B. Speakman ${ }^{20)}$ は. Milling Shrinkage を起すために

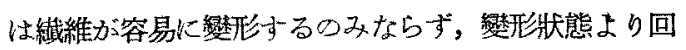
復する性質も同时飞もつていなければならない。Alkali milling では最適温度があるが. Acid milling た はこれがない，乙の事實は變形と變形のヒステレシス によつて說明されるという。向 Ethylene disulfide の作用につ、ては T. Barr \&. J: B. Speakman21) が別に報告している。Disulfide bonds を破鼠すると

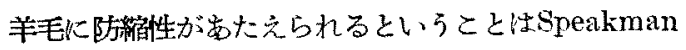


の持諭であるが A. J. Farnworth, W. J. P. Neish \& J. B. Speakman22)は (1) Thioglycolic acid で還 元して $\mathrm{Hg}^{\prime}(\mathrm{CN})_{2}$ で选理して-CH: S. Hg. S:OH一, (2)前と同心還元をして Trimethylene dibromide で

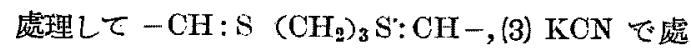
理してシスティンを Lanthione にして $-\mathrm{CH}_{2}-\mathrm{S}-$ $\mathrm{CH}_{2}$ ，(4) アルカリで處理して部分的に Lanthione KLて $-\mathrm{CH}_{2}^{\prime}-\mathrm{S}-\mathrm{CH}_{2}$ 等の結合を作り（想像的の もの)いつれも防樎性がすたえられることをのへてい、 る。

$\mathrm{S}_{2} \mathrm{Ol}_{2}$ の處理火關しては A. J. Farnworth \& J. B. Speakman23, の啹告がある。との方法は戰前有名 になつたるのであるが今日ては殆ど完成されていてと れ關する學術的の報告は比較的少ない。

一方彼は重合物を用万る防縮處理儿ついて一連の研 究蔡表している，卵ち W. J. P. Neish \& J. B. Speakman'4) は Silicon polymer dwin, T. Barr \& J. B. Speakman25) carboxyglycine t Et-acetateにとかして50 處理し，とれによつて水による重合を起させとれを Basic side chains そ結合させて防縮性を起させると いら方法登見した。又 M. Lipson \&J. B. Speakman ${ }^{26)}$ は Ferrous sulfate $\&$ Methylmethacrylate, $\mathrm{CH}_{2}$ : CHCN を用いて良好な防縮效果を得た。とれ によつて Wear resistance が墂し, 又伸長抵抗が著 しく㯰大するとのととでする。又 T. Barr, C.W. Cupp \& J. B. Spealkman27) \& Diisocyanate を用 いている。

以上重合物を用万る場合につれて綜合的に P. W. Moncrieff "8) 方解說している。重合物め防縮作用に つでスケールの Masking がその原因でるとい ら人も岁るが，後に出るようにこれに反對与る人るす り，未ど明確な解答は得られていない。

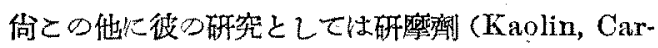
borundum, Silica, Fuller's earth, $\mathrm{Al}_{2} \mathrm{O}_{3}$ 等) を油 と混ぜて Milling を行つてスケールを取除き，てれ

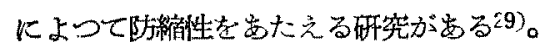

\section{文献}

（社 $\mathrm{OA}$ と菁いたのは Chemical Abstract の略, 印 别の部含上，例竞ば $2536^{2}$ は $2536-2$ とした)

1) E. H. Mercer J. Council Sci. Ind. Res., 18, 188-200, 1945, CA. 40, 467-5, 1946.

2) L, Bohn, $J$, Suc. Dyers \& Col, 61, 278-83,
1945, CA 40, 741-2, 1946

3) Mt. I.ipson \& P. Howard, $J$. \& Proceeding Roy. Soi. N. B. Wales, 791, 92-100, 1946, CA. 40, 7644-9, 1946,

4) N. Gralén \& B. Oleffson, Text. Res. J. 17, 4.88-96, 1947 CA. 41, 7757-h, 1947,

5) J. Lindberg \& Gralén, Text. Res. J. 18, 287 $-301,1948$, CA. 42, 5679-C, 1948,

6) J. Lindberg, Text. Res. J. 18, 470-4, 1948 , CA. 42, 7987-a, 1948,

7) J. Lindberg \& N. Gralén, Text. Res. J. 19, 183-201, 1949, CA. 43, 4857-i, 1949,

8) H. Buckle \& Pollitt, J. Text. Inst. 39, T 199 -210, 1948, CA. 42, 6122-i, 1948,

9) A. L. Smith \& M. Harris, Text. Res. J. 18, 475-80, 1948, CA. 42, 7986-i, 1948,

10) K. R. Makinson, Trane. Faraday Soc. 44, 278-82, 1948, CA. 43, 413-b, 1949,

11) H. T. Rothwell, J. Text. Inst. 33, T 15780, 1942, CA. 4253-2, 1942,

13) C. S. Whewell, M.A. M. Eid. \& N. Kokman \& M. C. Lui, J. Soc. Dyers \& Col. 59 , 233-40, 1943, CA. 38, 491-b 1944,

13) A. J. P. Martin, J. Soc. Dyers \& Col. 60, $395-8,1944$, CA. 39, 1057-8, 1945.

14) M. Harris, Am. Dyest. Reptr., 34, P 72-6, 1945, CA. $40212-6,1946$,

15) P. Alexander, I. Soc. Dyer \& Col., Sympo sium on Fibrous Protein, 1946, 199-206. CA. 41, 1447-i, 1947.

16) M. R. Freney, J. Sw. Dyer \& Col, Symposium on Fibrous Proteins, 1946, 78-92, CA. 41, 1450-d, 1947,

17) T. Ban \& J. B. Speakman, J. Soo. Dyers \& Col., 100, 335-40, 1944, CA. 39, 1057-1, 1945,

18) J. Menkart \& J. B. Speakman J. Soc. Dyers \& Col., 63, 322-4, 1947, CA. 42, 3735, 1948.

19) Nature, 156, 148, 1945, CA. 40, 2811-5,1946, 20) J. Menkart \& J. B. Speakman, J. Soc. Dyers \& Col., 64, 14-19, 1948, CA. 42, 2110b, 1948 .

21) T. Barr \& J. B. Speakman, J. Soc. Dyers \& Col., 40, 238-45, 1944, CA. 39, 1542-6, 1945, 
22) A. J. Farnworth, W. J. P. Neish \& J. B. Speakman, J. Soc, Dyers \& Col., 65, 447-58, 1949, CA. 44, 3ร5 i, 1950.

23) A. J. Farnworth \& J. B. Speakman, Nature, 161, 850-1, 1948, CA. 42, 6123-d. 1948 J. Soc. Dyers \& Col., 45, 162-b 1949, CA. 43, $5192-\mathrm{c}, 1949$.

24) W J. P. Neish \& J. B. Speakman, Natrre, 156, 176, 1945, CA. 40, 21-7, 1946.

25) A. W. Baldwin, T. Barr \& J. B. Speakman, $J$. Soc. Dyers \& Col., 62, 4-9, 1946, CA. 40, 2003-9, 1946.
26) M. Lipson \& J. B. Speakman, Nature, 157, 590, 1946 CA. 40, 4527-7, 1946, J. Sox. Dyers \&. Col., 65, 390-401, 1949, CA. 43, 8142-d, 1949 27) T. Barr.C. W. Capp. \& J. B. Speakman, $J$. Soc. Dyers \& Cul, 62, 838-45, 1946, CA. 41, 869-b, 1947 ,

28) R. W. Moncrieff, Text. Manuft., 75, $388-$ 91, 1949, OA. 43, 9457-b, 1949.

29) J. B. Speakman \& E. Whewell, J. Text. Inst., 76 T 48-56, 1945, CA. 39, 3435-9, 1945, U. S. 2,438, "328, March, 28, 1948, 